\title{
NEWS OF THE PROFESSION
}

\section{JESSE D. CLARKSON, 1897-1973}

Jesse Dunsmore Clarkson was born on August 6, 1897, and devoted most of his life to the education of thousands of students and colleagues. It is for this contribution that he will be most remembered. Dr. Clarkson graduated magna cum laude from Williams College in 1918 and received his M.A. degree in 1920 and $\mathrm{Ph} . \mathrm{D}$. in 1925 from Columbia University. He was a professor of history at Brooklyn College from its beginnings in 1930, served as the chairman of the Department of History from 1937 to 1950 , and was instrumental in building a teaching staff and instructional program which became known throughout the United States for its excellence. Dr. Clarkson retired from Brooklyn College in 1967 but continued his scholarly activities until his death on September 5, 1973.

Dr. Clarkson also had an international reputation which he earned primarily through his publications on European history. His major works are Labour and Nationalism in Ireland (New York and London, 1925); History of Russia from the Earlicst Times to the Rise of Commercial Capitalism by M. N. Pokrovsky, which he translated and edited with his wife, Mary Griffiths Clarkson (New York, 1930); War as a Social Institution (New York, 1941), which he edited; and $A$ History of Russia (New York, 1961, and subsequently reprinted). He also contributed to books and wrote several articles for various journals.

During his tenure at Brooklyn College, Dr. Clarkson was frequently a visiting professor at other institutions: Russian Institute of Columbia University (1952, 1954, 1956, 1958); University of California, Berkeley (spring 1962); lecturer, Office of War Information (1944-45) ; and lecturer, Staff Officers European Studies Course (1945-46). He was often a participant at historical conferences both at home and abroad. He traveled extensively throughout Europe and made several visits to the Soviet Union.

Jesse Clarkson was the epitome of an intelligent. He had a special magnetism in his classroom lectures and a certain charisma in his private discussions, all of which captured the imagination and interest of his students and colleagues alike. He brought life to otherwise dull subject matter and provoked a healthy suspicion about the causes of historical phenomena. In his professional and personal relations he mixed sharpness and kindness in such a manner as to remain an enigma to many who were searching for the "essence" of the man himself. Students and colleagues sought to emulate him, and as a result were likely to attain a more professional attitude and greater intellectual vitality.

\section{HeRBERT H. KapLAN Indiana University}

\section{VOJESLAV MOLE, 1886-1973}

Professor Molè was born December 14, 1886, in Kanal on the Soča River, some fifteen miles north of Gorica (Gorizia), Slovenia, Yugoslavia. The territory at that time was part of the Austro-Hungarian Empire. He received his early education 